Meta

Journal des traducteurs

Translators' Journal

\title{
The Poetry Translator as Dedicated Expert
}

\section{Francis Jones}

Volume 60, numéro 2, août 2015

$60^{\mathrm{e}}$ anniversaire. Les horizons de la traduction : retour vers le futur

$60^{\text {th }}$ Anniversary. Translation's Horizons: Back to the Future

60mo aniversario. Los horizontes de la traducción: regreso al futuro

URI : https://id.erudit.org/iderudit/1032895ar

DOI : https://doi.org/10.7202/1032895ar

Aller au sommaire du numéro

Éditeur(s)

Les Presses de l’Université de Montréal

ISSN

0026-0452 (imprimé)

1492-1421 (numérique)

Découvrir la revue

Citer ce document

Jones, F. (2015). The Poetry Translator as Dedicated Expert. Meta, 60(2),

344-344. https://doi.org/10.7202/1032895ar d'utilisation que vous pouvez consulter en ligne.

https://apropos.erudit.org/fr/usagers/politique-dutilisation/ 


\title{
The Poetry Translator as Dedicated Expert
}

\author{
Francis Jones \\ Newcastle University, Newcastle upon Tyne, UK \\ francis.jones@ncl.ac.uk
}

James S. Holmes (1924-1986) was not only a founding father of Translation Studies: he was also one of his generation's leading Dutch-English poetry translators. This paper analyses Holmes's poetry-translation and translation-editing career as a case study of a "dedicated expert": someone who plays a central role in communicating literature from a language of limited diffusion to readers of another language (Zabic and Kamenish 2006). It argues that interpersonal networks are central to a dedicated-expert role. Using Holmes's poetry-translation publications as sources, it then charts how he gradually built networks with living Dutch-language poets, with other poetry translators as a co-translator, editor and mentor, and with fellow editors and publishers.

The paper's underlying aim is methodological. Bourdieu's call for biography to analyse how someone acts as an "agent efficient" in various social fields, each with its own set of agents (1986), appears especially relevant to a dedicated expert's career. Network-based analyses of how translators, writers, editors, etc. interact in publishing projects or in workplaces can arguably map action within fields more incisively than Bourdieu's macrosocial approach. Such analyses, however, rarely extend beyond individual projects. This paper explores whether plotting a dynamic 'web of networks' through time and across projects (extending Jones 2011) is enough to explain complex translation-production roles like the dedicated poetry-translation expert - or whether macrosocial concepts like habitus and power might also be needed.

Francis Jones is Reader in Translation Studies at Newcastle University. He has translated or cotranslated 21 collections of poetry from Dutch and Bosnian-Croatian-Serbian (plus Hungarian and Russian) into standard and regional Englishes, and has won 14 translation prizes. His research focuses on poetry translation, with interests ranging from cognitive processes via interpersonal networks to ideology and identity in poetry translating. 